\title{
Language Changes of Indonesian Conjunctions on Literary Of 1844, 1922 And 2005
}

\author{
Riswani \\ Universitas Indonesia \\ Awardee of Indonesia Endowment Fund for Education
}

\begin{abstract}
This paper reports on a study that investigates the use of Indonesian conjunctions as hope/purpose marker in the sentences, i.e., agar, biar and supaya. It examines how the conjunctions used century by century and the syntactic pattern occurred after conjunctions are analysed. It used reanalysis method on the sub clause to find out syntactic pattern constructed. Data were taken from three century of literary, such as: $18^{\text {th }}, 19^{\text {th }}$ and $20^{\text {th }}$ literary. Then, it also used http://mcp.anu.edu.au/ to get the occurrence frequencies of the three conjunctions on $18^{\text {th }}$ and $19^{\text {th }}$ century literary; and AntConc software for $20^{\text {th }}$ literary. The results showed that: 1) based on the data, conjunction agar is not found in $18^{\text {th }}$ century literature but it is mostly used as marker of hope/purpose in $20^{\text {th }}$ literary. It is contrast with conjunction supaya where conjunction supaya is mostly used in $18^{\text {th }}$ and $19^{\text {th }}$ literary, but it is very rarely used in in $20^{\text {th }}$ literacy. 2) The conjunction biar gets extended function in $19^{\text {th }}$ and $20^{\text {th }}$ century, it not only shows hope/purpose but also shows contradictive things or ability to something. 3) The three conjunctions agar, biar and supaya also get change on syntactic pattern in the sub clause, especially the structure of subject and predicate; and constructing complete or incomplete clause.
\end{abstract}

Keywords: conjunctions, Indonesian, language change, syntactic pattern

\section{Introduction}

Conjunctions are often referred to as connecting words so it can be said that conjunctions are words that connect one word class to another word class, phrase with phrase, clause with clause in sentence. In addition, conjunctions are also called connector / linker of words (Slametmuljana, in Nardiati \& et al, 1996: 1). The use of conjunctions is bound to the syntactic construction of clauses in the sentence. In its use, the conjunction has various types and it can be seen from the position of its use.

As time goes by, changes occur in all areas of science having a significant impact on people's lives, including changes of language. Language changes can occur at all levels of the language itself, either at the phonological, morphological, syntactic, semantics or lexicon levels. Changes 
usually occur on the rules of language, whether the rules change, the rule is revised, the rule is not used even disappear or there is a new rule.

The change usually begins with the emergence of language variations by the community in using the language to communicate with others. These language variations bring up new rules or new words alongside their use with old or old words. New variations of language and current language will be used in common. Kinds of variations not is used will be disappear and it is one of causes of language changes. Language variations also occur at the conjunctional level and result in language and function changes in clauses, especially in conjunction markers of hope / purpose.

Therefore, this study discusses the use of conjunctions in the Indonesian language, especially the conjunction marker of the meaning of hope / purpose as the object of the research, namely: agar, biar, and supaya. The three conjunctions are synonymous and can substitute each other's position in the sentence. Conjunctions are always attached to subclause.

The pattern of Conjunction in Indonesia is commonly used:

$$
\begin{aligned}
& \text { Main Clause + Agar/Biar/Supaya + Subclause } \\
& \text { "Independent Clause + agar/biar/supaya + Dependent Clause" } \\
& \text { Agar/Biar/Supaya + Klausa Terikat, Klausa Bebas } \\
& \text { "agar/biar/supaya + Subclause, Main Clause" }
\end{aligned}
$$

For example (Nadiati \& dkk, 1996):

1. Pemimpin koperasi harus mempunyai sifat demokratis supaya keberadaan koperasi mendapat dukungan dari masyarakat.

2. Pemimpin koperasi harus mempunyai sifat demokratis agar keberadaan koperasi mendapat dukungan dari masyarakat.

3. Pemimpin koperasi harus mempunyai sifat demokratis biar keberadaan koperasi mendapat dukungan dari masyarakat.

Since the three conjunctions are synonymous and can be substituted, some questions arise about them such as: 1) whether the three conjunctions used have been used together from long ago; 2) whether the sub clause following the three conjunctions is the same from the past until now; 3) which conjunction is most commonly used for first time from until now; 4) which conjunction is most commonly used now; and 5) whether there has been a change in by the times. Therefore, this study has aims, such as: 1) describe how the use of conjunctions agar, biar, and supaya in sentence in the 18th century, 19th and 20th literary; 2) describe the most commonly used conjunctions in the Indonesian language today; and 3) show and describe whether there is any change in function of the conjunction or not. In addition, this study also figures out and describes the syntactic patterns that occur in the sub clause following the conjunction, whether the clause is complete or clause is incomplete. 


\section{Analytical Framework}

Language is a tool of communication that humans use to convey intent or idea to others. In its use, the language is dynamic to follow the development of the times so that the language is always experiencing changes that are not realized by humans about when, where and how the language changed. This is similar to what Chaer (1995) argues that language is dynamic, so language that language can changes by term of times. The change takes a long time so it is quite difficult to observe at the time of the change. These changes can only be determined after they show evidence of such language changes. There are two types of language changes, namely the unwitting changes and changes directed by the language planner.

The process of language change varies greatly. Poedjosoedarmo (2009) mentions at least there are two kinds of change process that can be identified, namely: 1), internal changes and external changes. Internal changes usually occur in the grammatical system of a language and the change takes a long time and slowly. Internal change is essentially a change that occurs from within the language itself in its grammatical system. External changes include changes caused by influences from other languages or the presence of language contacts. This change can happen with a relatively quick process and this change usually begins with the lexicon's riches. With the development and change of language, language can change both in terms of structure and word variation.

Language variation has an important role to change a language. Milroy (1992) states that the variation of language used by the community in communicating as the starting point of a language change. These variations can occur at the level of lexicons to the syntactic level. The existence of language variations, such as new words, will affect the extension of the old word whether it will still be used, decreased or extinct in the presence of another lexicon or just a new word is only temporary use in society. Thus, variations and language changes are two things that can't be separated in language development.

Campbell (2004) explains that there are three main foundations for finding and describing language changes, namely: 1) reanalysis, 2) expansion and 3) borrowing. The reanalysis approach focuses on structures in the syntactic order. Expansion does not refer to the construction of a word order, phrase, clause or sentence, but emphasizes its wider use, whether it is widespread meaning or wider usage. Borrowing is related to the presence of contact languages with other languages. However, the study discusses more and deals only with language changes using reanalysis.

This study discusses the changes of Indonesian conjunctions on the level of frequency of use or on the level of syntax. Indonesian conjunctions are agar, biar dan supaya as a marker of hope/purposes. These changes include word order, use of verbs, and affixing clauses in sentences. Chomsky $(1957,1965)$ explains that the first syntactical framework sees linguistic theory as a major part of the rule formulation. The structure of language consists of rules, structural descriptions and structural changes. Thus, the rules of language structure may change with the passage of time to facilitate humans in the communication process. 


\section{Method}

The present research involves the creation of a small corpus of contemporary Indonesian writing, from a literary genre, a novel; the use of publicly available corpus analysis software, AntConc; and http://mpc.anu.edu.au/.

This study uses literary works as instruments data consisting of hikayat and novel in three periods of time, namely Maharaja Marakarma Hikayat (1844 or 1849), Novel Siti Nurbaya (1922) and Novel Laskar Pelangi (2005). Distance period of literary works between one another is around 70 more years. In addition, each literary work has a token about 90 thousand more words.

In addition, this study discusses two basic points, namely 1) description of the frequency of conjunction agar, biar and supaya from time to time, and 2) syntactic patterns in sentences, especially clauses which are the object of study to be reviewed. Furthermore, this study uses a combined method of quantitative and qualitative methods. The quantitative method uses the base of the corpus in the form of Antcon application to see how the frequency distribution of conjunction usage in the literary works in those three periods. Qualitative methods are used to describe the findings and analyze the findings by reanalysis method.

Research steps: 1) determine the type of literary works with three periods of time, namely the 18th, 19th and 20th centuries; 2) using http://mpc.anu.edu.au/ to determine the distribution of the three conjunctions in the 18th century; and the AntConc app knows its distribution of distribution in the nineteenth and twentieth centuries; 3) mapping the distribution of conjunction usage agar, biar and supaya into tables and diagrams; and 4) describe the patterns in the clause following the three conjunctions, whether the complete clause or not.

\section{Finding and Discussion}

1. Description of usage frequency of conjunctions agar, biar dan supaya as a marker of hope / purpose from time to time

a. Hikayat Maharaja Marakarma

Hikayat Maharaja Mahakarma is one of the 18th century literary works. The work was published around 1844 / 1848. The following table uses the frequency of conjunctions to let and in the 18th century:

Table Frequency of Conjunction Use of agar, biar and supaya in the 18th Century

\begin{tabular}{|l|l|l|l|}
\hline No & Conjunctions & Frequencies of use & Percentage (\%) \\
\hline 1 & Agar & 0 & $0 \%$ \\
\hline 2 & Biar & 2 & $0.002 \%$ \\
\hline 3 & Supaya & 65 & $0.067 \%$ \\
\hline Total & $\mathbf{6 7}$ & $\mathbf{0 . 0 6 9 \%}$ \\
\hline Notes: & \\
Number of words: 96.747 & \\
Frequencies of others words: $96.747-67: 96.680(99,93 \%)$ & \\
\hline
\end{tabular}


The table above shows that in the 18th century, there was no use of conjunctions agar in the literature of Hikayat Maharaja Marakarma used to express purpose or hope, the author uses conjunction biar and supaya where the conjunction supaya is most widely used.

b. Novel Siti Nurbaya

Novel Siti Nurbaya is one of the works of 19th century literature. The novel was written by Marah Rusli and published by Balai Pustaka in Jakarta in 1992. The following table frequency of conjunction use so that, let and so in the 19th century:

Table Frequency of Conjunction Use of agar, biar and supaya in the 19th Century

\begin{tabular}{|l|l|l|l|}
\hline No & $\begin{array}{l}\text { Conjunction } \\
\text { s }\end{array}$ & Frequencies of use & \\
\hline 1 & Agar & 2 & Percentage (\%) \\
\hline 2 & Biar & 27 & $0.002 \%$ \\
\hline 3 & Supaya & 233 & $0.03 \%$ \\
\hline \multicolumn{2}{|l|}{ Total } & $\mathbf{2 6 2}$ & $0.247 \%$ \\
\hline
\end{tabular}

Notes:

Number of words: 94.112

Frequencies of others words: 94.112 - 262: $938.50(99,7 \%)$

The table above shows that in the 19th century, the use of conjunctions supaya is still the most used conjunction in literary works to express purpose / hope, while the conjunction agar is to be used even though the frequency of its use is still very small compared to the other two conjunctions.

\section{c. $\quad$ Novel Laskar Pelangi}

Novel Laskar Pelangi is one of the literary works of the 20th century. The novel is about education. In addition, the novel was written by the famous author in Indonesia, Andrea Hirata and published by Bentang Pustaka in Jogyakarta in 2005. The following table frequency of conjunction use so that, let and so in the 20th century:

Table Frequency of Conjunction agar, biar dan supaya in the 20th century

\begin{tabular}{|l|l|l|l|}
\hline No & $\begin{array}{l}\text { Conjunction } \\
\text { s }\end{array}$ & Frequencies of use & Percentage (\%) \\
\hline 1 & Agar & 67 & $0.07 \%$ \\
\hline 2 & Biar & 7 & $0.007 \%$ \\
\hline 3 & Supaya & 1 & $0.001 \%$ \\
\hline Total & $\mathbf{7 5}$ & $\mathbf{0 . 0 7 8 \%}$ \\
\hline $\begin{array}{l}\text { Notes: } \\
\text { Number of words: } 98.043\end{array}$ \\
Frequencies of others words: $98.043-75: 97.968(99,9 \%)$ \\
\hline
\end{tabular}

The table above shows that the use of conjunctions agar, biar dan supaya as markers of purpose / hope is very different in the 20th century than in previous centuries. Frequency of conjunction agar is the most in using and conjunction supaya is used at least in Laskar Pelangi novel.

d. The use of conjunctions by the times 
Conjunctions agar, biar dan supaya get increased and decreased usage in sentences from century to century. The increase and decrease result in language changes. Here is a description of the three conjunctions from century to century in the tables and diagrams to give an easy and clear picture!

Table use of conjunctions agar, biar dan supaya as markers of purpose / hope from century to century

\begin{tabular}{|l|l|l|l|l|}
\hline \multirow{2}{*}{ No } & \multirow{2}{*}{ Conjunctions } & Period & \multicolumn{3}{l|}{} \\
\cline { 3 - 5 } & & $\mathbf{1 8 4 4}$ & $\mathbf{1 9 2 2}$ & $\mathbf{2 0 0 5}$ \\
\hline 1 & Agar & 0 & 2 & 67 \\
\hline 2 & Biar & 2 & 27 & 7 \\
\hline 3 & Supaya & 65 & 233 & 1 \\
\hline
\end{tabular}

The table above shows that there a possibility of a change of conjunctions use as markers of purpose / hope from century to century, namely:

$>\quad$ In the 18th century, the use of conjunctions supaya is the most used in sentences and conjunctions agar is not found its use;

$>\quad$ In the 19th century, the use of conjunctions supaya still has the highest frequency of use and conjunctions agar is began to be used in the sentence of the century;

$>\quad$ In the 20th century, the use of conjunctions agar has the highest frequency in the sentence to show purpose / hope, while the conjunction supaya that has started rarely used and it is proved data findings that show range about 1 ;

$>\quad$ The use of conjunctions biar is still frequent and its use may be said to be static from century to century. However, the use of conjunctions biar can also be used to express other things, not only for marking purpose/hope (in the discussion of the description of the syntactic patterns in the sub clause).

Besides that, the use of conjunctions agar, biar dan supaya can be also illustrated in the graph below:

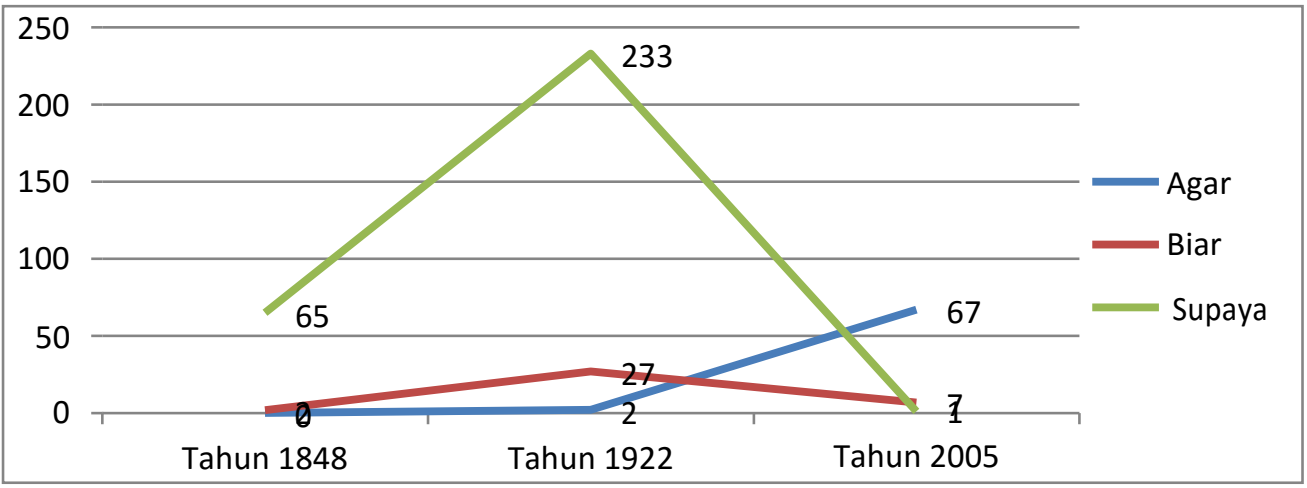

Graph of the use of conjunctions agar, biar dan supaya from century to century

From the graph, the use of conjunctions agar, biar dan supaya is very clearly seen the difference from the past until now. The use of conjunctions supaya rarely used now and more often found the use of conjunctions agar to express the purpose / hope. Moreover, conjunction biar also 
decrease but is not bigger conjunction supaya. However, the findings mentioned above still need to be studied further related to language changes because the data used is still very small. But the findings can be used as a starting point for further research.

e. Description of the distribution of conjunctions agar, biar and supaya nowdays

To support the findings obtained on the use of conjunctions agar, supaya dan biar where conjunctions agar is are used more often than conjunctions supaya significantly to express purpose/hope in the sentence, this study uses a larger scale corpus to see the distribution of its use. The corpus contains data from twenty literary works of the 20th century that can at least represent the use of conjunctions on written, such as: Antologi Rasa (2015), Belahan Jiwa (2012), Cantik itu Luka (2002), Catatan Istri Seorang Istri (2011), Cerita Cinta Enrico (2012), Cinta di dalam Gelas (2010), Daun yang Jatuh tak Pernah Membenci Angin (2011), Di Tanah Lada (2015), Hafalan Shalat Delisa (2008), Hujan dalam Teduh (2011), Lelaki Harimau (2004), Mata di Tanah Melus (2018), Milea Suara dari Dilan (2016), Perahu Kertas (2010), Sabtu Bersama Bapak (2014), Pulang (2012), Sang Penandai (2011), dan Surga Sungsang (2013). The corpus has a total of words about 1,197,243 words. The following table frequency of conjunction use order, let and so in the 20th century:

Table Frequency of Conjunction agar, biar dan supaya in the 20th century

\begin{tabular}{|l|l|l|l|}
\hline No & $\begin{array}{l}\text { Conjunction } \\
\text { S }\end{array}$ & Frequencies of use & Percentage $(\boldsymbol{\%})$ \\
\hline 1 & Agar & 670 & $0.06 \%$ \\
\hline 2 & Biar & 226 & $0.02 \%$ \\
\hline 3 & Supaya & 127 & $0.01 \%$ \\
\hline \multicolumn{2}{|l|}{ Total } & $\mathbf{1 . 0 2 3}$ & $\mathbf{0 . 0 9 \%}$ \\
\hline $\begin{array}{l}\text { Notes: } \\
\text { Number of words: } 1.197 .243\end{array}$ \\
\hline
\end{tabular}

The data above indicates that the data is in line with previous findings that conjunctions agar is the most commonly used conjunctions in expressing hope/purpose. Conjunctions supaya is still used but the frequency is decreasing. In addition, conjunctions biar also has a sufficient usage frequency of about 226. However, the use of conjunctions biar is not only used to express hope/purpose but also to state other things. The shift of the function is obtained after seeing the whole sentence. Conjuction biar is not only be used as a marker of hope / purpose with the number of 175 frequencies and 51 frequencies are also used as a conjunction to convey other things such as:

$>\quad$ state abilities (15 frequencies) to do something or to help someone

For example:

"Sabar Dik, biar Abang yang bereskan persoalan ini"

The sentence states the ability of a person, in this case Abang, to help in solving problems faced by others (Dik, salutation for younger people in Indonesia).

$>\quad$ The state of contrast (16 frequencies) to describe a condition contrary to something stated in the main clause.

For example:

"biar saja ku tak setegar batu karang tapi selalu kucoba melindungimu” 
The sub clause is against the main sentence.

$>$ Besides that, there are 20 uses of conjunction biar that cannot be classified into conjunctions and it consists of the phrase "biar bagaimanapun" about 15 frequencies, "biar saja "about 4 frequencies and state the solicitation.

\section{For example:}

i. biar bagaimanapun, Akew adalah kawanku dan kawanmu tapi bagiku dia lebih dari Cuma seorang kawan

ii. Biar saja.

iii. Biar kita bareng aja.

As the conclusion, the conjunctions agar, supaya dan biar are still used by the society in communicating until now. However, the frequency of conjunction agar is most used as a marker of hope / purpose. Then, conjunctions biar also get shifting usage functions not only used as a marker of hope / purpose but also for expressing ability and contrast.

2. Syntactic patterns in the clause.

This study also discusses on how syntactic patterns that follow the use of conjunctions in Indonesian as markers of purpose / hope from 1844 to present. In this case, the focusing description is done on the sub clause by paying attention to the syntactic patterns in the order of the word function in the clause. The syntactic pattern that follows the conjunction is complete or incomplete clause. Complete clause consists of Subject (S) and Predicate (P), whereas incomplete clauses usually have only predicate. Here is a description of the syntactic pattern that follows the conjunction in the sub clause:

a. Agar

1) 1992

In 1992 or the 19th century, the emergence of conjunction agar in the novel Siti Nurbaya about 2 times with different patterns. The pattern is as follows:

- $\quad$ "Dan diberilah ia kuasa atas segala yang harus dikuasainya agar jangan sama ia dengan boneka yang bernyawa"

"Dan diberilah ia kuasa atas segala yang dikuasainya" is main clause consisting S P. "agar jangan sama ia dengan boneka yang bernyawa" is sub clause having pattern $\mathrm{P}+\mathrm{S}$. Subject is "ia" and the predicate is adjective "sama".

- "ada pula yang membuat agar madunya itu lekas berkalang tanah"

"ada pula yang membuat" is main clause and having pattern S + P. "agar madunya itu lekas berkalang tanah" is sub clause and also having pattern S + P.

Thus, the conjunction agar is used in sentence in the literary work of 1992 by forming Subject + Predicate and Predicate + Subject. It is complete clause. 
2) 2005

The use of conjunctions agar increase in the literary works of the 2005 period in which the novel Laskar Pelangi as a sample. The pattern is as follows:

- "Dahan-dahan, ranting yang digunakan untuk menyumbat agar ahiran air tidak bocor."

The sentence consists of the main clause in the form of " Dahan-dahan, ranting yang digunakan untuk menyumbat " and the sub clause of " agar ahiran air tidak bocor" The sub clause has a subject and predicate with the S P pattern where the subject in the clause is a phrase and an adjective as a predicate. Sub clause has complete clause

- $\quad$ banyak pula yang menunggu seumur hidup agar bakatnya atau dirinya ditemukan.

"banyak pula yang menunggu seumur hidup" is main clause and "agar bakatnya atau dirinya ditemukan" is sub clause. Sub clause has complete clause and the pattern is $\mathrm{S}+\mathrm{P}$. Subject is "bakatnya atau dirinya" and "ditemukan" is verba as predicate.

- $\quad$ agar mengambil tindakan praktis

The clause is not complete clause and it has only predicate verba "mengambil"

- $\quad$ agar diselamatkan

The clause is not complete clause and it has only predicate verba. It is passive verba "diselamatkan"..

\section{- agar lungsur}

The clause is not complete clause and it has only adjective as predicate. The adjective is "lungsur".

- $\quad$ agar tidak tergelincir

The clause is not complete clause and it has only intransitive verb as predicate. The verb is "tergelincir".

As the conclusion, the conjunction agar is followed by complete clauses and incomplete clauses in the sentence in the 2005's literary work. The complete clause is patterned $\mathrm{S}+\mathrm{P}$. The incomplete clause has the predicate of active, passive, intransitive, and adjective verbs.

b. Biar

1) $\quad 1848$

The use of conjunctions biar only appears twice in the literary works of the period 1844 . The pattern is as follows:

- "biar ia himpunkan balatentaranya"

The clause is complete clause and consists of subject and predicate. The pattern is $\mathrm{S}+\mathrm{P}$. "ia" is subject and "himpunkan" is verba as predicate..

- "biar tetap hati adinda tuan memegang negeri tuan"

The clause is complete clause having subject and predicate. The pattern is S + P. "hati adinda" is subject and "memegang" is verba as predicate in sub clause.

Thus, the conjunction biar in the novel data is followed by a complete clause patterned $\mathrm{S}+\mathrm{P}$ 
2) 1922

In 1922 or the 19th century, the emergence of conjunctions biar gets an increase of 27 times its appearance on the novel Siti Nurbaya. The pattern is as follows:

- $\quad$ biar yang setahun ini menjadi sehari.

The clause is complete clause dan has pattern S + P. "yang setahun ini" is frase as subject and "menjadi" is verba as predicate.

- $\quad$ biar bodoh asal pandai

The clause is not complete clause and the predicate is adjective.

- $\quad$ biar aku rugi beribu sekalipun

The clause is complete clause and has subject and predicate. The pattern is $\mathrm{S}+\mathrm{P}$. Besides that, "aku" is subject and the predicate is verba "rugi".

- $\quad$ biar diambil orang

The clause is not complete clause and the predicate is passive verb "diambil".

Thus, the conjunction biar is followed by a complete clause and an incomplete clause in the sentence in the literary work of 1922 . The complete clause is patterned $\mathrm{S}+\mathrm{P}$. The incomplete clause has the predicate of active verb, passive verbs, intransitive verbs, and adjectives.

3) $\quad 2005$

Use of conjunction biar is about 7 frequencies of occurrence in novel Laskar Pelangi. The pattern is as follows:

- $\quad$ biar Abang bereskan persoalan ini

The clause following conjunctions biar is complete clause and the pattern is S + P. "Abang" is subject and "bereskan" is verb as predicate.

- $\quad$ biar segera mengambil kapur itu

The clause is incomplete clause and only has verb "mengambil" as predicate.

Thus, conjunctions biar can be followed by complete clauses and incomplete clauses. The complete clause pattern is $\mathrm{S}+\mathrm{P}$.

c. Supaya

1) $\quad 1844$

The use of conjunctions supaya is about 65 frequencies on literary works of the period of 1844 . The pattern is as follows:

- $\quad$ supaya aku balas

The clause following conjunctions supaya is complete clause dan the pattern is $\mathrm{S}+\mathrm{P}$. "aku" is subject and "balas" is verb as predicate in the sub clause.

- $\quad$ supaya boleh menggantikan taktha kerajaan ayahmu dan nenenda

The clause is incomplete clause where "menggantikan" is active verb as predicate.

- $\quad$ supaya diperbuat persalin

The clause is complete clause and has subject "persalin" and predicate "diperbuat" where "diperbuat" is passive verb as predicate. The pattern is $\mathrm{P}+\mathrm{S}$

- $\quad$ supaya hilang rasanya rindu

The clause is complete clause and has subject "persalin" and predicate "diperbuat" where "diperbuat" is passive verb as predicate. The pattern is $\mathrm{P}+\mathrm{S}$.

Thus, the conjunction supaya in novel data is followed by a complete clause and an incomplete clause in the sentence in the literature of 1844 . The complete clause is patterned $\mathrm{S}+\mathrm{P}$ and $\mathrm{P}+\mathrm{S}$. The incomplete clause has a verb predicate and adjective. 
2) 1922

Conjunction use of supaya is about 233 frequency of its appearance in novel Siti Nurbaya. The pattern is as follows:

- $\quad$ supaya ada penghidupan kita

The clause following conjunctios supaya is complete clause. The pattern is $\mathrm{P}+\mathrm{S}$. "ada" is intransitive verb as predicate and "penghidupan kita" is subject in the sub clause.

- $\quad$ supaya dapat baik kembali

The clause is not complete clause and the predicate is adjective "baik".

- $\quad$ supaya dapat bertemu kembali dengan dia

The clause is not complete clause and "bertemu" is verb as predicate.

- $\quad$ supaya anak itu disekolahkan

The clause is complete clause and the pattern is S + P. Subject is "anak itu" and the predicate is "disekolahkan". The pattern is $\mathrm{S}+\mathrm{P}$.

- $\quad$ supaya kenyang perutnya

The clause following conjunctios supaya is complete clause. The pattern is $\mathrm{P}+\mathrm{S}$. "kenyang" is adjective as predicate and "perutnya" is subject in the sub clause.

- $\quad$ supaya jangan terlalu lelah engkau

The clause following conjunctios supaya is complete clause. The pattern is $\mathrm{P}+\mathrm{S}$. "lelah" is adjective as predicate and "engkau" is subject in the sub clause.

Thus, the conjunction supaya is followed by complete clauses and incomplete clauses in the sentence in the literary work of 1922 . The complete clause is patterned $\mathrm{S}+\mathrm{P}$ and $\mathrm{P}+\mathrm{S}$. The incomplete clause has predicate of active verb, passive verb, intransitive verb, and adjective.

3) 2005

The use of conjunction supaya is about 1 frequency of occurrence in Laskar Pelangi novel. The pattern is as follows:

- $\quad$ supaya kedap air

In $20^{\text {th }}$ century's novel, there is imcomplete clause following conjunctions supaya. The predicate is "kedap" adjective

However, it does not mean a conjunction supaya followed only by an incomplete clause as in the findings in this novel. This is because the data source is still limited. Therefore, this study also uses a syntactic pattern on the corpus consisting of the two novels and obtains the result that conjunctions are also followed by complete clauses and incomplete clauses. The complete clause is patterned $\mathrm{S}+\mathrm{P}$.

For example:

$\begin{array}{ll}\text { i. } & \text { supaya Bu Tukang sate percaya } \\ \text { ii. } & \text { supaya cantik }\end{array}$

The clause in the first example is complete clauses and the patterns are patterned $\mathrm{S}+\mathrm{P}$, while the third example is incomplete clauses with only a predicate. 
To clarify the findings of the data obtained in the three literary works by looking at the use of conjunctions in the clause, the following data are obtained:

\begin{tabular}{|c|c|c|c|c|c|c|c|c|c|c|c|c|c|c|c|c|}
\hline \multirow{4}{*}{ No } & \multirow{4}{*}{ Conjuntions } & \multicolumn{15}{|c|}{ The Construction of Syntac Pattern } \\
\hline & & \multicolumn{5}{|c|}{1844} & \multicolumn{5}{|c|}{1992} & \multicolumn{5}{|c|}{2005} \\
\hline & & \multirow[b]{2}{*}{ S P } & \multirow[b]{2}{*}{ P S } & \multicolumn{3}{|c|}{$\mathrm{P}$} & \multirow[b]{2}{*}{ S P } & \multirow[b]{2}{*}{ P S } & \multicolumn{3}{|c|}{$\mathrm{P}$} & \multirow[b]{2}{*}{ S P } & \multirow[b]{2}{*}{ P S } & \multicolumn{3}{|c|}{$\mathrm{P}$} \\
\hline & & & & $\mathrm{V}$ & Adj & $\mathrm{N}$ & & & $\mathrm{V}$ & Adj & $\mathrm{N}$ & & & $\mathrm{V}$ & Adj & $\mathrm{N}$ \\
\hline 1 & Agar & - & - & - & - & - & 2 & - & - & - & - & 27 & - & 42 & 7 & - \\
\hline 2 & Biar & 2 & - & - & - & - & 5 & - & 7 & 14 & 2 & 4 & - & 3 & - & - \\
\hline 3 & Supaya & 39 & 15 & 8 & 1 & 1 & 94 & 27 & 92 & 18 & 2 & - & - & - & 1 & \\
\hline
\end{tabular}

\section{Conclusions}

1. Generally, conjunction agar, biar dan supaya are used to state or express hope/purpose

2. The three conjunctions agar, biar dan supaya are getting increasing and decreasing in using the conjunctions by society to communicate. Conjunction agar is getting increasing from $19^{\text {th }}$ century until now and based on the data discussed, conjunction agar is the most used in communicating even written or spoken. Contrary, conjunction supaya is getting decreasing by the times.

3. Generally, the syntactic patterns following the three conjunctions have the same pattern, Subject + Predicate. Then, they are followed by complete clause and incomplete clause in the sub clause in sentences.

4. There is language change in syntactic level on using conjunction in sub clause, especially using conjunction supaya starting 1844 until now. In 1844 and 1922, there are two patterns following conjunctions supaya in sub clause, such as $\mathrm{S}+\mathrm{P}$ and $\mathrm{P}+\mathrm{S}$. Then, in 2005 until now, there is only one pattern following conjunction supaya and it is $\mathrm{S}+\mathrm{P}$.

5. Conjunctions biar is getting function change in stating clauses. It indicates not only state as marker of hope/purpose, but also it can declare the other things, such as ability to do something, showing contractive, etc.

\section{References}

Aitchison, Jean. 1991. Language Change Progress or Decay. Cambridge: Cambridge University Press.

Campell, Lyle. 2004. Historical Linguistics: An Introduction (Second Edition). Edinburgh: Edinburgh University Press.

Chaer, Abdul. 1990. Penggunaan Preposisi dan Konjungsi Bahasa Indonesia. Jogjakarta: Nusa Indah.

Chaer, Abdul dan Leoni Agustina. 1995. Sosiolinguistik Perkenalan Awal. Jakarta: Rineka Cipta. Chaer, Abdul dan Leonie Agustina. 2004. Sosiolinguistik: Perkenalan awal. Edisi Revisi. Jakarta: PT. Rineka Cipta.

Chamber, J.K., Peter Trudgill and Natalie Schiling-Estes(Eds). 2003. The Handbook of 
Language Variation and Change. Blackwell Publishing. Blackwell Reference Online. 31 December 2007.

Chomsky, N. 1957. Syntactic Structures. The Hague: Mouton

Chomsky, N. 1965. Aspects of the Theory of Syntax. Cambridge, MA: MIT

Milroy, James.1992. Linguistic Variation and Change. On the Historical Sociolinguistic of English. Oxfod and Cambridge. MA: Blackwell.

Nardiati, Sri \& dkk. 1996. Konjungsi Subordinatif dalam Bahasa Indonesia. Jakarta: Pusat Pembinaan dan Pengembangan Bahasa. Depdikbud.

Parera, J.D. 2009. Dasar-Dasar Analisis Sintaksis. Jakarta: Erlangga.

Poedjosoedarmo, S. 2006. Perubahan Tata Bahasa: Penyebab, Proses, dan Akibatnya. Yogyakarta: Universitas Sanata Dharma. 